\title{
Studies on the Nutritional, Mineral Composition, Mineral Ratio and Anti-nutritional Molar Ratio of Six Underutilized Wild Edible Vegetables in Ado-Ekiti, Ekiti State, Nigeria
}

\author{
Modupe Janet Ayeni ${ }^{a^{*}}$ and Sunday Dele Oyeyemi ${ }^{\mathrm{a}}$ \\ ${ }^{a}$ Department of Plant Science and Biotechnology, Ekiti State University, 36001, Ado- Ekiti, Nigeria.
}

Authors' contributions

This work was carried out in collaboration between two authors. Authors MJA and SDO designed the study and collection of samples. Author SDO wrote the protocol of the work. Author MJA wrote the first draft of the manuscript. Authors MJA and SDO managed the analyses and literature searches. The two authors MJA and SDO proof read and approved the final manuscript. Both authors read and approved the final manuscript.

\section{Article Information}

DOI: $10.9734 / A R R B / 2021 / v 36 i 1230467$ Editor(s):

(1) Dr. Md. Torequl Islam, Federal University of Piaui, Brazil.

Reviewers:

(1) Daniela Helena Pelegrine Guimarães, São Paulo University, Brazil.

(2) Jorge Octavio Virues Delgadillo, Universidad Veracruzana, México. Complete Peer review History, details of the editor(s), Reviewers and additional Reviewers are available here: https://www.sdiarticle5.com/review-history/78788

Original Research Article

Received 07 October 2021

Accepted 15 December 2021 Published 16 December 2021

\begin{abstract}
Aim: Fruits and common vegetables are now becoming too expensive for the poor consumers in Nigeria. The search for cheap, readily available and (locally sourced for the people in need of) nutritious food prompted this research work.

Study Design: Six underutilized wild vegetables (Solanum microcarpon, Strichium sparganophora, Crassocephalum crepidiodes, Solanum nigrum, Myrianthus arboreus and Sterculia tragacantha) from Ado- Ekiti, Ekiti State, Nigeria were evaluated for their nutritional, mineral and anti-nutritional potentials.

Place and Duration of Study: The collection of the samples were done in the month of December, 2020 in Ado Ekiti, Ekiti State, Nigeria and air dried for three weeks.

Methodology: Young shoots of five indigenous vegetables were collected, washed thoroughly, air dried, pulverized and analysed using standard methods of AOAC.
\end{abstract}


Results: The proximate analyses of the vegetables indicated that the moisture content, ash, fat, crude fiber, crude protein and carbohydrates ranged as follows: $6.17-8.85 \%, 4.73-6.59 \%, 2.00-$ $3.13 \%, 3.89-7.27 \%, 7.77-12.23 \%$ and $63.84-70.61 \%$ respectively. The total energy ranged from $1,367.85$ to $1,467.85 \mathrm{KJ} / 100 \mathrm{~g}$ with low Coefficient of Variation (CV\%) of 2.22. Mineral contents are of the following order $\mathrm{K}>\mathrm{Mg}>\mathrm{Ca}>\mathrm{P}>\mathrm{Na}>\mathrm{Fe}>\mathrm{Zn}$. The result of the mineral ratio showed that the calculated mineral ratio for $\mathrm{Na} / \mathrm{K}, \mathrm{K} / \mathrm{Na}, \mathrm{Ca} / \mathrm{P}, \mathrm{Ca} / \mathrm{Mg}, \mathrm{Ca} / \mathrm{K}, \mathrm{Zn} / \mathrm{Cu}$ and $[\mathrm{K} /(\mathrm{Ca}+\mathrm{Mg})]$ were below the critical level. The calculated mineral safety indexes (MSI) were lower than the tabulated values. The anti-nutrient contents (Cyanide, Saponins, and Oxalate) were below the threshold levels,

Conclusion: Low MSI means that the vegetables could not pose health risk when consumed. The low anti-nutrient contents of the samples is an indication that the consumer would not suffer from mineral overload. The nutrition and mineral potentials of these vegetables could suggest their uses as nutritional supplements and are highly promising for food security and sustainability for the populace.

Keywords: Proximate; vegetables; Crassocephalum crepidiodes; Myrianthus arboreus; Sterculia tragacantha; Strichium sparganophora.

\section{INTRODUCTION}

People's health in the recent times is deteriorated due to unbalance nutrition, excessive consumption of discretionary foods and drinks with unhealthy way of life. This has resulted to increased rate of chronic diseases, diabetes, respiratory disorders, cardiovascular diseases, obesity which led to increased mortality worldwide. Szakaly [1] reported that chronic diseases represent almost $45.9 \%$ of all diseases worldwide. To prevent these deadly diseases, efforts must be intensified by humans to change their pattern of life and consume balanced diets of plant based rich in vegetables and fruits. The importance of indigenous leafy vegetables in the health care of humans cannot be under-estimated. Green leafy vegetables are important constituent of human diet in many part of Nigeria, West Africa and worldwide. Vegetables play an important role in human nutrition and being mostly low in fat and high in vitamins minerals and dietary fiber [2,3]. In Nigeria and Africa as a whole, leafy vegetables have a vital role in the food culture of the people [4]. Olowoake and Adebayo [5] noted the increasing awareness of the value of the leafy vegetables in that they contribute to balanced diet in areas where animal protein is difficult. Also, Eroarome [6] noted that leafy vegetables have continued to provide populations with limited access to meat and fish, a rich source of protein and macronutrients essential for pregnant and lactating mothers as well as young and growing children.

Some of the vegetables are cultivated while some occur in the wild [7]. Champton [8] described Wild Edible Vegetables (WEVs) as the vegetables that grow spontaneously in selfmaintaining population in natural or in seminatural ecosystem. It plays a vital role as food in time of food scarcity in the rural areas. WEVs contribute significantly to dietary fibre requirement of rural household [9]. Apart from the nutritional potentials of vegetables, they also have medicinal values. Vegetable neutralizes stomach acidity and aid digestion [10] and quite useful in traditional medicine [11]. The medicinal values of the vegetables might have been attributed to some chemical substances which produces definite physiological action in human body [12]. Some phytochemicals in vegetables are strong antioxidants and are known to reduce the risk of chronic diseases by protecting against free radical damage, modifying metabolic activation detoxification of carcinogenic diseases or even influencing that alter the course of tumour cells $[13,14]$.

Robinson [15] reported that there are different types of vegetables and each group contributes in its own way to human diet. The indigenous vegetables play a major role in the time of food scarcity in the rural areas. Previous studies had reported that in most local Nigerian diets approximately half of the leafy vegetables consumed are from wild plants and this constituting significant micronutrient sources in time of drought and famine [16,17]. The indigenous vegetables are mostly consumed among rural dwellers because they are cheap and have potentials in combatting hunger $[18,19]$. Apart from promoting good health, increased consumption of African indigenous vegetables can also help enhance crop diversity, alleviate poverty and promote food security. 
Despite the fact that the vegetables are nutritious with medicinal values, recent initiatives revealed that the consumption of wild edible vegetables is declining particularly in Nigeria [20]. In the previous work of Schneider et al. [21] and MMWR [22], it was reported that the consumption of fruits and vegetables are below the recommended intake among adults despite the increasing focus on their health benefits. However, many of these cheap or inexpensive wild plants are yet to be adequately studied and their nutritional potential to human health has not been fully exploited [23].

Hence, the present study was designed to determine the proximate values, mineral compositions, mineral ratio, mineral safety index and anti-nutritional factors of six selected indigenous wild edible vegetables in Ado- Ekiti, Nigeria.

\section{MATERIALS AND METHODS}

\subsection{Collection and Preparation of Sample}

The young shoots with matured leaves of indigenous vegetables (Solanum macrcarpon, Strichium sparganophora, Crassocephalum crepidiodes and Solanum nigrum) were obtained from Oba's market, Ado Ekiti while those of Myrianthus arboreus and Sterculia tragacantha were obtained from farmlands in Ado Ekiti. The leaves were separated from the shoots, rinsed with water and air dried for three weeks. The air dried leaves were pulverized into powdery form and stored separately in a covered plastic rubber at ambient temperature for further analysis.

\subsection{Methodology}

\subsubsection{Proximate analysis}

Proximate analysis of the powdered samples was carried out to determine moisture, ash, crude fiber and crude fat using standard methods [24], protein was determined by the Kjeldahl method [25] while Carbohydrate was determined by the difference.

\subsubsection{Moisture content determination}

Moisture content of the powdered samples was determined using [24] method. The sample $(5 \mathrm{~g})$ was weighed into already weighed clean dry cans. The cans with the samples were then placed in the oven at $105^{\circ} \mathrm{C}$ to dry until constant weight on drying after which the final weight were taken as:
$\%$ Moisture Content $(\mathrm{MC})=\underline{\mathrm{W}}_{1} \frac{-\mathrm{W}_{2}}{\mathrm{~W}_{3}} \times \frac{100}{1}$

Where

$\mathrm{W}_{1}=$ Weight of empty can; $\mathrm{W}_{2}=$ Weight of can + sample before drying; $\mathrm{W} 3=$ Weight of can + sample after drying.

The dry matter was used in the determination of other parameters. The protein content was determined using Micro Kjedhal method by multiplying the total organic nitrogen by 6.25 [24]. Carbohydrate content was determined by the differences obtained after subtracting the total Nitrogen protein, lipid, ash, fiber from the total dry matter and expressed as percentage [24].

Available Carbohydrate $=(100-\%$ moisture $+\%$ ash $+\%$ protein $+\%$ Fibre) .

Ash continent was determined by incineration of $10.0 \mathrm{~g}$ samples placed in a muffle furnace maintained at $550{ }^{\circ} \mathrm{C}$ for $5 \mathrm{~h}$. Crude fibre was obtained by digesting $2.0 \mathrm{~g}$ of the samples with $\mathrm{H}_{2} \mathrm{SO}_{4}$ and $\mathrm{NaOH}$ and incinerating the residue in a muffle furnace maintained at $550{ }^{\circ} \mathrm{C}$ for $5 \mathrm{~h}$. Crude fat was obtained exhaustively by extracting $5.0 \mathrm{~g}$ of the sample in Soxhlet apparatus using petroleum boiling range of $40-60$ ${ }^{0} \mathrm{C}$ as extract.

\subsection{Determination of Mineral Compositions}

One gram (1g) of the powdered sample was digested with $10 \mathrm{ml}$ of concentrated Nitric acid, $3 \mathrm{ml}$ of $60 \%$ Perchloric acid and $1 \mathrm{ml}$ of concentrated $\mathrm{H}_{2} \mathrm{SO}_{4}$. After cooling, the digested material was diluted with $50 \mathrm{ml}$ de-ionised distil water filtered with Whatman No 42 filler paper and the filtrates were made up to $100 \mathrm{ml}$ in a glass volumetric flask with de-ionised distil water. Filtered solutions were used to determined $\mathrm{Zn}, \mathrm{Fe}, \mathrm{Mn}, \mathrm{Cu}, \mathrm{Pb}$ and $\mathrm{Cd}$ by means of Atomic Absorption Spectrophotometer (Bulk Scientific 210 VP Spectrophotometer). The macroelements Sodium and Potassium were analysed by Flame Photometer-Jenway (FP) 902 unit-122. Phosphorus was analysed by Jenway 6 Compressor. All chemical reagents used are of British Drug House (BDH, London, UK) analytical grade.

\subsection{Determination of Energy}

Energy content was calculated using Atwater factor method as described by Osborne and Voogt [26]. The estimated energy value in the 
samples in Kilocalorie (Kcal/100g) was determined by adding the multiplied values for crude fat, crude protein and carbohydrate using the factor $(9 \mathrm{Kcal}, 4 \mathrm{Kcal}$ and $4 \mathrm{Kcal}$ ) respectively. The energy value in Kilojoule was determined by adding the multiplied values for crude fat, crude protein and carbohydrate using the factor (37Kcal, 17Kcal and 17Kcal) respectively.

\subsection{Determination of some Anti-nutrient substances}

The Oxalate content was determined using High Pressure Liquid Chromatograph (HPLC) methods described by Wilson et al. [27] while Phytate and Cyanide were determined according to methods described by Wheeler and Ferrel [28] and AOAC [29] respectively.

\subsection{Other Calculations}

Other calculations were made from the mineral elements include mineral ratios and Mineral Safety Index (MSI).

\subsubsection{Determination of molar ratio of phytate/ mineral}

The mole of phytate and minerals was determined by dividing the weight of phytate and minerals with its atomic weight (Phytate: 660g/mol.; Fe: 55.85g/mol.; Zn: 65.38g/mol.; Ca: $40.08 \mathrm{~g} / \mathrm{mol}$.). The molar ratio between phytate and mineral was obtained after dividing the mole of phytate with the mole of mineral.

\subsubsection{Calculation of the mole ratio}

The [phytate]: [Zn], [Ca]: [phytate], [phytate]: [Fe] and [Ca] [phytate]: $[\mathrm{Zn}]$ mole ratios were calculated as previously described by Wyatt et al. [30], Izincg [31].

\subsection{Statistical Analysis}

Descriptive statistics (mean, standard deviation and coefficient of variation) [32] were determined and all data were subjected to Chi-square $\left(x^{2}\right)$ test to determine significant differences among the results obtained [33].

\section{RESULTS AND DISCUSSION}

\subsection{Proximate Composition}

The proximate composition of the leaves of six selected indigenous vegetables for this study is presented in Table 1. The moisture content in the wild leafy vegetables revealed that the obtained values were low. The values ranged from $6.17 \%$ in $S$. macrocarpon to $8.85 \%$ in S.nigrum. When compared statistically, there was no significant difference in the moisture content of $C$. crepidiodes and $M$. arboreus as well as moisture content in S. sparganophora and $S$. tragacantha. The moisture content values were low compared to values of $28.29 \%$ and $20.3 \%$ in Vitex doniana and Bombax boupoense respectively [34]. The values were also lower than $83.90 \%$ reported for the leaves of $M$. arboreus [35].However, the values were higher than the value recorded in the leaves of $S$. microcarpon reported by llodibia [36]. The low moisture content recorded in the vegetables might be attributed to the period of collection of samples during the dry season / harmattan which was associated with intensive heat, sunlight and dryness with low rainfall. The low moisture content recorded in these vegetables might reduce bacterial and fungal action thereby reducing the spoilage of the vegetable leaves. Adeyeye and Adejuyo [37] had earlier reported that the lower moisture content prevents leaves from spoilage by microorganisms. Also, Udousoro and Ekanem [38] affirmed that low moisture content of vegetables would reduce the activity of water soluble enzymes and co- enzymes needed for metabolism of the leaves.

Crude protein content ranged between $8.94 \%$ in Solanum nigrum to $12.23 \%$ in Sterculia tragcatha. The result revealed the protein content in order Sterculia tragacantha $>C$. crepidiodes $>$ Myrianhus arboreus $>S$. macrocarpon > S. nigrum > Strichium sparganophora. The protein contents in the vegetables were significantly different to each other, that of $C$. crepidiodes and $M$. arboreus showed no significant difference. Likewise protein content in $S$. microcarpon and $S$. nigrum showed no significant difference. The protein contents recorded in this study were higher than the value (7.44\%) reported for Vitex doniana [34]. However, the values were lower compared to $16.40 \%$ reported by Amata [35].

The vegetables contained appreciable amount of crude protein. Lai [39] noted that protein in the form of amino acids in the nutrient needed by human body for growth and maintenance. Protein is an important part of diet that is used in building and repair of tissues [37]. Plant food that provides more than $12 \%$ of its caloric value from protein is considered as a good source of protein 
[40]. The vegetables evaluated were rich in crude protein and could be recommended as good sources of crude protein. In addition, the vegetables could be consumed together with other dishes to meet protein deficiency among the rural dwellers. The crude fiber obtained in the vegetables ranged between 3.89 in $C$. crepidiodes to $7.27 \%$ in S. macrocarpon. The crude fibre content in $S$. tragacantha was significantly higher than other vegetables in this study. The crude fiber content in this study were higher than the previous reports of Oyeyemi et al. [41] on Sparganophora spargophora (3.74\%). However, the values were lower compared to the range of $10.40-30.10 \%$ reported by Akinwumi and Omotayo [42]. The moderate quantity of crude fiber in the wild vegetables is in accordance with the submission of Sobowale et al. [43] who reported that leafy vegetables are rich in dietary fiber. Fiber plays a vital role in cleansing digestive tract and increase faeces consistency [34,44]. It has also been reported that fiber helps in reducing blood sugar and also act as general body purifier [45].

Crude fat in the wild vegetables were low and ranged between $2.00 \%$ in Strichium sparganophora to $3.13 \%$ in $S$. tragacantha respectively. The results also lend credence to the work of Akinwumi and Omotayo [42] who reported low crude fat level in Basela alba $(3.01 \%)$, Corchorus olitorius $(2.55 \%)$ and Solanum macrocarpon (3.01\%). The crude fat contents obtained for the six vegetables in this study were lower than values reported in Gossypium hirsutum leaves $(6.57 \%)$ and Momordica chaantia (5.83\%) [46]. The crude fat content of the vegetables in this study was low and can be as part of weight reducing diet. The low values of crude fat obtained in these vegetables suggest that the leaves are poor sources of lipids. The crude fat level in these vegetables suggests that their leaves are poor sources of lipids. The result of the present work conforms to the findings of other researchers who reported that leafy vegetables are poor sources of lipids $[47,48]$. Hence, they could be a good diet for people suffering from obesity $[43,49]$. Ash content of the vegetables ranged between $4.73 \%$ in C. crepidiodes to $6.76 \%$ in Strichium sparganophora. Comparatively, the values were lower than the values reported for Piper guineensis $(7.73 \%)$ and 0 . gratisimum $(9.67 \%)$ [48]. Ash content obtained in leafy vegetables is a reflection of the amount of mineral elements in food [50]. Earlier work of Ifon and Basir [51] reported that leafy vegetable with ash content greater than $8.8 \%$ are healthful.

The carbohydrate content in the leaves of the vegetables ranged between $63.84 \%$ in Sterculia tragacantha to $70.61 \%$ in Strichium sparganophora. The carbohydrate content in the investigated vegetables are in order of Strichium sparganophora $>C$. crepidiodes $>S$. macrocarpon $>S$. nigrum $>M$. arboreus $>S$. tragacantha. The carbohydrate contents as reported in this present study were higher than $45.20 \%$ in S. tragcantha and $39.40 \%$ in S. indicum [52]. The consumption of carbohydrate may provide the body with fuel and energy that is required for daily activities and exercise [38]. High carbohydrate in the vegetables implied that all the vegetables might be a very useful source of energy.

\subsection{Metabolizable Energy}

The proportion of total energy contribution from crude fat, crude protein and carbohydrate to total energy is shown in Table 2. The results of the total metabolizable energy obtained in this work revealed high energy level for the six selected wild edibles. The total metabolizable energy was higher than the values reported in Crassocephalum crepidiodes $(308.45 \mathrm{Kcal} / 100 \mathrm{~g})$ and Crassocephalum rubens $(302.91 \mathrm{Kcal} / 100 \mathrm{~g})$ in previous work of Adjatin et al. [53]. However, the values were low when compared with the values reported by Min et al. [54] for Lomariopsis guineensis $(440.37 \mathrm{Kcal} / 100 \mathrm{~g})$ and Penniseum purpureum $(364.98 \mathrm{Kcal} / 100 \mathrm{~g})$. Carbohydrate had the highest percentage energy contribution followed by protein.

The results of utilizable energy due to protein (PEP\%) in this present study were cheering. The values ranged between 132.09 to $297 \mathrm{Kj} / 100 \mathrm{~g}$. It is generally recommended that plant food providing more than $12 \%$ of its calorific value from protein is a good source of protein. This implies that the vegetables are good sources of protein and would provide between $9.38 \%$ $14.59 \%$ energy to total metabolizable energy. The values of utilizable energy due to protein (UEDP\%) were lower than 8\% recommended for safe level for adult man who requires about $55 \mathrm{~g}$ protein per day with $60 \%$ utilization. The PEF\% results albeit low would be good for people wishing to adopt diet containing low lipid content. Low level of lipids plays a significant role in preservation of chronic diseases such as liver cirrhosis, diabetes and heart related diseases [55]. 
Table 1. Proximate composition of Six Selected Wild Edible Vegetables

\begin{tabular}{|c|c|c|c|c|c|c|}
\hline Vegetables & Moisture content (\%) & Ash (\%) & Crude Fat (\%) & Crude fibre (\%) & Crude protein (\%) & Carbohydrate (\%) \\
\hline Solanum macrocarpon & $6.17 \pm 0.19 d$ & $5.98 \pm 0.23 b c$ & $2.70 \pm 0.30 a b$ & $7.27 \pm 0.24 a$ & $8.98 \pm 0.06 c$ & $68.89 \pm 0.66 a$ \\
\hline Strichium sparganophora & $7.03 \pm 0.15 c$ & $6.76 \pm 0.35 a$ & $2.00 \pm 0.01 \mathrm{c}$ & $5.85 \pm 0.15 a b$ & $7.77 \pm 0.30 \mathrm{~d}$ & $70.61 \pm 0.35 a$ \\
\hline $\begin{array}{l}\text { Crassocephallum } \\
\text { crepidiodes }\end{array}$ & $8.03 \pm 0.27 b$ & $4.73 \pm 0.26 d$ & $2.43 \pm 0.14 \mathrm{bc}$ & $3.89 \pm 0.19 c$ & $10.87 \pm 0.48 b$ & $70.04 \pm 0.16 a$ \\
\hline Solanum nigrum & $8.85 \pm 0.23 a$ & $6.32 \pm 0.13 a b c$ & $2.87 \pm 0.20 \mathrm{ab}$ & $4.57 \pm 0.59 b c$ & $8.94 \pm 0.01 \mathrm{c}$ & $68.45 \pm 0.29 a b$ \\
\hline Myrianthus arboreus & $7.97 \pm 0.03 b$ & $6.59 \pm 0.04 a b$ & $2.42 \pm 0.19 b c$ & $6.99 \pm 0.04 a$ & $10.43 \pm 0.48 b$ & $65.44 \pm 1.01 \mathrm{bc}$ \\
\hline Sterculia tragacantha & $8.25 \pm 0.36 c$ & $5.64 \pm 0.44 \mathrm{c}$ & $3.13 \pm 0.40 a$ & $6.01 \pm 1.37 a b$ & $12.23 \pm 0.18 a$ & $63.84 \pm 2.88 \mathrm{c}$ \\
\hline
\end{tabular}




\subsection{Mineral Composition}

The amount of Sodium in the leaves of the selected six vegetables ranged from 49.35 $\mathrm{mg} / 100 \mathrm{~g}$ in S. sparganophora to $90.25 \mathrm{mg} / 100 \mathrm{~g}$ in S. tragacantha (Table 3). It was revealed that the vegetables have higher $\mathrm{Na}$ contents. The results are similar to the values reported by Olujobi [34] on Lecanoidisus cupanoides, Albizia glaberrima and Bombax bounopozense. However, $\mathrm{Na}$ level in the vegetables were lower compared to those reported on Crassocephalum crepidiodes $(2213.43 \mathrm{mg} / 100 \mathrm{~g})$ and 2129.04 $\mathrm{mg} / 100 \mathrm{~g}$ Crassocephalum rubens [53]. $\mathrm{Na}$ functions in the regulation of body fluid and in the maintenance of electrical potential in the body [56]. The ratio of $\mathrm{Na}: \mathrm{K}$ in the body is of great concern for the prevention of hypertension [57].

The mineral compositions of the vegetables studied as shown in Table 3 revealed that Potassium level were higher in Solanum nigrum leaves $(280.25 \mathrm{mg} / 100 \mathrm{~g})$, C. crepidiodes $(264.40$ $\mathrm{mg} / 100 \mathrm{~g}), M$. arboreus $(227.0 \mathrm{mg} / 100 \mathrm{~g}$ ) and Sterculia tragacantha $(216.40 \mathrm{mg} / 100 \mathrm{~g})$, however, these values were lower than the $908.10 \mathrm{mg} / 100 \mathrm{~g}$ Potassium recorded by Oibiokpa et al. [58] in the fruit of Detarium microcarpon. Soetan et al. [59] noted that Potassium plays an important role in the regulation of osmotic pressure, muscle contraction particularly cardiac muscle, cell membrane function and $\mathrm{Na}^{+} / \mathrm{K}^{+}$ATPase. High concentration of potassium in the body was reported to increase iron utilization [59]. Calcium content in the vegetables ranged between 48.15 $\mathrm{mg} / 100 \mathrm{~g}$ in Strichium sparganophora to $151.55 \mathrm{mg} / 100 \mathrm{~g}$ in $C$. crepidiodes. Higher calcium content recorded in the vegetables showed the vegetables are good source of calcium. Calcium and Phosphorus are required for bone teeth formation as well as maintenance and can also help in blood clothing, muscle contraction and regulation of cell permeability [60]. Calcium deficiency leads to osteoporosis and higher risk of fracture [61].

The results of Phosphorus concentrations in the six vegetables under study ranged from 28.30 $\mathrm{mg} / 100 \mathrm{~g}$ in Strichium sparganophora to 66.09 $\mathrm{mg} / 100 \mathrm{~g}$ in $C$. crepidiodes. The results showed that the vegetables are rich source of Phosphorus. Phosphorus levels in this study were lower compared to $75.22 \mathrm{mg} / 100 \mathrm{~g}$ Phosphorus in the leaves of $S$. nigrum [62] but were higher than those obtained in the leaves of O. grattisimum $(13.8 \mathrm{mg} / 100 \mathrm{~g}), V$. amygdalina
$(13.1 \mathrm{mg} / 100 \mathrm{~g}$ ) and $15.08 \mathrm{mg} / 100 \mathrm{~g}$ for Telferia occidentalis [43]. Magnesium content in the leaves of the selected vegetables revealed high occurrence of $\mathrm{Mg}$. in C. crepidiodes $1195.85 \mathrm{mg}$ $/ 100 \mathrm{~g})$ and $S$. nigrum $(189.15 \mathrm{mg} / 100 \mathrm{~g})$, while other four vegetables have moderate quantity of Mg. Magnesium is vital in human nutrition due to its functions as a co-actor for more than 300 essential enzyme systems. Wardlaw et al. [60] reported that Mg controls blood glucose level and support healthy immune. Also, Okon et al. [52] noted that $\mathrm{Mg}$ is important for nerves and heart function, increase insulin and decreases blood dilating arteries and preventing abnormal heart rhythm. The iron $(\mathrm{Fe})$ contents in the vegetables under study were low. Adeyeye and Otoketi [63] noted that iron is essential for blood formation and normal functioning of central nervous system. Wardlaw et al. [60] also reported that Fe is important in immune functions, cognitive development, temperature regulation and energy metabolism.

The results of Manganese, Copper and Zinc in the vegetables revealed low concentration of these trace elements. These elements are needed in little quantity in food. They help in many physiological and biological functions in the body. Copper is required for enzyme production and biological electron transport [56]. Zinc is very useful in protein synthesis, cellular differentiation and replication, immunity and sexual functions in fertility [64]. Very low levels of toxic metals (Pd, $\mathrm{Cd}$ and $\mathrm{Ni}$ ) were recorded in the six vegetables investigated. $\mathrm{Pd}$ was not recorded in $S$. macrocarpon and Strichium sparganophora, Cd was not found $C$. crepidiodes, S. nigrum and $S$. tragacantha while $\mathrm{Ni}$ was absent in $C$. crepidiodes. High concentration of toxic metals in food could be deleterious to human health. The very low levels of these toxic metals in the vegetables could not pose any threat to human health and could make them to be considered safe for human consumption.

\subsection{Mineral Ratio}

The calculated mineral ratios for the six selected wild edible vegetables are shown in Table 4. The importance of minerals cannot be underestimated considering their physiological and metabolic functions in the body. The $\mathrm{Na} / \mathrm{K}$ ratio for the samples with exception of $M$. arboreus were good. A diet source having $\mathrm{Na} / \mathrm{K}$ ratio less than 1 has been reported to impact in lowering blood [56]. The vegetables would be useful in good diet for treating or preventing 
blood pressure problems. The $\mathrm{Ca} / \mathrm{P}$ ratios were above 0.5 and the results were advantageous and would promote the development of strong bone. The ratio of Calcium to Magnesium intake has gained attention in recent years. Deluccia et al. [65] reported that a ratio above 2:1 has been associated with increased risk of metabolic, inflammatory and cardiovascular disorder. The $\mathrm{Ca} / \mathrm{Mg}$ ratio of the selected vegetables is in order and could not cause any harm to the consumer.

The miliequivalent ratio $[\mathrm{K} /(\mathrm{Ca}+\mathrm{Mg})]$ in the six selected edible vegetables were lower than the ideal value of 2.2. The low level was as a result of high level of $\mathrm{Ca}$ and $\mathrm{Mg}$ in the vegetables.

The $\mathrm{Zn} / \mathrm{Cu}$ and $\mathrm{Fe} / \mathrm{Cu}$ ratios were below the ideal values. The toxic ratio of $\mathrm{Ca} / \mathrm{Pb}$ and $\mathrm{Fe} / \mathrm{Pb}$ in $S$. sparganophora and C.crepidiodes and $\mathrm{Zn} / \mathrm{Cd}$ in $M$. arboreaus and $S$. tragacantha could not be determined due to the absence of Lead and Cadmium in the vegetables.

The calculated mineral safety index of $\mathrm{Na}, \mathrm{Mg}, \mathrm{P}$, $\mathrm{Ca}, \mathrm{Fe}, \mathrm{Zn}$ and $\mathrm{Cu}$ in the vegetables (Table 5) were lower than the calculated values (TV). This implies that the investigated vegetables might not be overloading the body in any of the minerals.

\subsection{Anti-nutritional Factors}

The anti- nutritional factors of the six selected wild edible vegetables are shown in Table 6.

Anti-nutritional factors reduce the bioavailability of nutrients in food substances. However, they play a vital role on determining the use of plants as human food and animals feed [66]. Phytate has long been identified as a potential inhibitor of $\mathrm{Ca}, \mathrm{Fe}, \mathrm{Cu}, \mathrm{Zn}$ and $\mathrm{Mn}$ absorption [67] The Phytate contents in these vegetables were higher than $2.76-9.90 \mathrm{mg} / 100 \mathrm{~g}$ recorded for staple cereal foods commonly consumed in Zaria, Nigeria. However, the values were lower than $59.9 \%$ for phytate content of Synsepalum dulcificum leaves [68]. The daily intake of phytate for humans on vegetarian diet, on an average is $2000-2600 \mathrm{mg}$ while for rural dwellers in developing countries, on mixed diets, is 150 $1,400 \mathrm{mg}$ [69].

Cyanide is a highly toxic element and has been implicated as a causative agent in certain diseases [70]. The WHO recommended safe limit is $10 \mathrm{mg}$ of $\mathrm{HCN} / \mathrm{kg}$ body weight [71]. The results of the cyanide in this finding were higher than the recommended level hence the vegetables should be consumed with caution. Albeit, the antinutritive substances can be made ineffective or their levels can be reduced with treatments such as soaking and cooking. With the exception of $S$. sparganophora, Oxalate levels in the six selected wild edible vegetables were higher than the level of $40-50 \mathrm{mg}$ per day recommended by the American Diabetic Association [72] for the patient suffering from kidney stone problems. Higher consumption of Oxalate in food could be fatal because of the formation of calcium oxalate deposits in vital tissues or organs of the body [73].Several studies have reported that different cooking and soaking processing methods can significantly reduce various anti-nutritional compounds [74,75] and also improve the nutritional quality of food [76]. Ertop and Bektop [67] reported that oxalate content in taro samples decreased by at least $47 \%$ when boiled in water for 40mins. The fear of high oxalate content in these vegetables could be allayed through soaking and cooking processes before eating.

The influence of Phytate on the bioavailability of minerals depends not only on the Phytate levels in the diet but also on the interaction between Phytate and minerals. The Phytate to mineral ratios give better prediction of the inhibitory effect of Phytate on the bioavailability of minerals. Estimated Phy: $\mathrm{Zn}$ molar ratios of $S$. macrocarpon, S. sparganophora, C. crepidiodes and $S$. nigrum leaves were below the critical level, suggesting that Phytate level might not affect Zinc bioavailability in these selected vegetables. However, the estimated Phy/Zn molar ratios for $M$. arboreus and $S$. tragacantha leaves were above the critical level $(\geq 10)$, hence suggesting that the phytate might impaired Zinc bioavailability in these two wild vegetables. Phy/Zn molar ratio of 15 showed that $\mathrm{Zn}$ absorption is adversely affected and results in negative $\mathrm{Zn}$ balance [77]. The Phytate: Fe molar ratios less than one (1) have been reported to be desirable for iron bioavailability [78]. The Phy/Fe values in this study were greater than one (1) with $M$. arboreus and $S$. tragacantha having relatively higher Phy/Fe molar ratios of 6.91 and 6.42 respectively. The high $\mathrm{Phy} / \mathrm{Fe}$ ratios suggest poor iron bioavailability for all six selected vegetables. Low iron bioavailability led to the etiology of iron deficiency anaemia [79]. The results obtained may pose some problem especially to the rural dwellers that depends on wild vegetables for source of iron. 
Table 2. Proportion of percentage contribution from fat, protein and carbohydrate to total energy

\begin{tabular}{|c|c|c|c|c|c|c|c|c|c|}
\hline Parameter & $\mathbf{A}$ & B & C & D & $\mathbf{E}$ & $\mathbf{F}$ & Mean & SD & CV\% \\
\hline \multicolumn{10}{|l|}{ Total energy } \\
\hline $\mathrm{E}$ in $\mathrm{kJ} / 100 \mathrm{~g}$ ) & $1,423.69$ & $1,406.46$ & $1,465.38$ & $1,421.82$ & $1,367.85$ & $1,421.92$ & $1,417.85$ & 31.48 & 2.22 \\
\hline $\begin{array}{l}\text { (E in kcal/100g) } \\
\text { PEF \% }\end{array}$ & 335.78 & 331.52 & 345.51 & 335.30 & 322.61 & 335.49 & 334.37 & 7.41 & 2.21 \\
\hline (E in kJ/100g) & 99.90 & 74.00 & 89.91 & 106.19 & 95.09 & 115.81 & 114.52 & 49.83 & 43.51 \\
\hline \multicolumn{9}{|l|}{ PEP \% } & 43.50 \\
\hline$(E$ in $k J / 100 g)$ & 152.66 & 132.09 & 184.79 & 151.98 & 177.31 & 207.91 & 167.79 & 27.36 & 16.31 \\
\hline$(E$ in $\mathrm{kcal} / 100 \mathrm{~g})$ & 35.92 & 31.08 & 43.48 & 35.76 & 41.72 & 48.92 & 39.48 & 6.44 & 16.31 \\
\hline \multicolumn{10}{|l|}{ PEC \% } \\
\hline$(E$ in $k J / 100 g$ ) & $1,171.13$ & $1,200.37$ & $1,190.68$ & $1,163.65$ & $1,095.45$ & $1,098.2$ & 1153.24 & 45.65 & 3.95 \\
\hline \multirow{2}{*}{\multicolumn{9}{|c|}{ UEDP \% }} & 3.97 \\
\hline & 91.60 & 79.25 & 110.87 & 91.19 & 106.39 & 124.75 & & 16.42 & \\
\hline (E in kcal/100g) & 21.55 & 18.65 & 26.09 & 21.46 & 25.03 & 29.35 & 23.69 & 3.80 & 13.45 \\
\hline
\end{tabular}

$P E F=$ proportion of total energy due to fat; $P E P=$ proportion of total energy due to protein; $P E C=$ proportion of total energy due to carbohydrate; UEDP = utilization of $60 \%$ of $P E P \%$.

$K E Y: A=$ Solanum macrocarpon, $B=$ Strichium sparganophora, $C=$ Crassocephallum crepidiodes

$D=$ Solanum nigrum, $E=$ Myrianthus arboreus,$F=$ Sterculia tragacantha

Table 3. Mineral composition of Six Studied Wild Edible Vegetables $(\mathrm{mg} / 100 \mathrm{~g})$

\begin{tabular}{|c|c|c|c|c|c|c|c|c|c|c|c|c|c|c|}
\hline \multirow[t]{2}{*}{ Parameter } & \multicolumn{6}{|c|}{ Samples } & \multirow[t]{2}{*}{ Total } & \multirow[t]{2}{*}{ Mean } & \multirow[t]{2}{*}{ SD } & \multirow[t]{2}{*}{ CV\% } & \multirow[t]{2}{*}{$\operatorname{Min}(x)$} & \multirow[t]{2}{*}{$\operatorname{Max}(x)$} & \multirow[t]{2}{*}{$x^{2}$} & \multirow[t]{2}{*}{ Remark } \\
\hline & A & B & C & D & $E$ & $\mathbf{F}$ & & & & & & & & \\
\hline $\mathrm{Na}$ & 55.50 & 49.35 & 66.60 & 74.20 & 74.95 & 90.25 & 410.85 & 68.45 & 14.74 & 21.53 & 49.35 & 90.25 & 15.87 & $\mathrm{~S}$ \\
\hline $\mathrm{K}$ & 82.25 & 68.70 & 264.75 & 280.25 & 227.0 & 216.40 & 1139.35 & 189.89 & 91.78 & 48.33 & 68.70 & 280.25 & 160.82 & $S$ \\
\hline$P$ & 38.98 & 28.30 & 66.09 & 71.55 & 45.65 & 58.26 & 308.83 & 51.47 & 16.67 & 32.39 & 28.30 & 71.55 & 27.00 & S \\
\hline $\mathrm{Ca}$ & 61.02 & 48.15 & 151.55 & 138.50 & 102.55 & 130.66 & 632.43 & 105.41 & 42.71 & 40.52 & 48.15 & 155.55 & $2,721.6$ & S \\
\hline $\mathrm{Mg}$ & 24.68 & 27.71 & 195.85 & 189.15 & 10.79 & 12.15 & 460.33 & 76.75 & 89.95 & 117.24 & 10.79 & 195.85 & 526.85 & S \\
\hline $\mathrm{Mn}$ & 0.23 & 0.51 & 0.14 & 0.25 & 0.51 & 0.43 & 2.07 & 0.35 & 0.16 & 45.14 & 0.14 & 0.51 & 0.349 & NS \\
\hline $\mathrm{Fe}$ & 2.07 & 1.80 & 1.11 & 1.39 & 0.59 & 0.72 & 7.68 & 1.28 & 0.59 & 46.09 & 0.59 & 2.07 & 1.3479 & NS \\
\hline $\mathrm{Zn}$ & 1.46 & 1.15 & 0.68 & 0.83 & 0.32 & 0.29 & 4.72 & 0.78 & 0.46 & 58.97 & 0.29 & 1.46 & 1.3635 & NS \\
\hline $\mathrm{Cu}$ & 0.83 & 0.57 & 0.41 & 0.44 & 0.53 & 0.67 & 3.45 & 0.58 & 0.16 & 27.58 & 0.41 & 0.83 & 0.1560 & NS \\
\hline $\mathrm{Pb}$ & 0.00 & 0.00 & 0.01 & 0.02 & 0.03 & 0.06 & 0.12 & 0.03 & 0.021 & 70 & 0.00 & 0.06 & 1.0026 & NS \\
\hline
\end{tabular}




\begin{tabular}{|c|c|c|c|c|c|c|c|c|c|c|c|c|c|c|}
\hline \multirow{2}{*}{ Parameter } & \multicolumn{6}{|c|}{ Samples } & \multirow{2}{*}{ Total } & \multirow{2}{*}{ Mean } & \multirow{2}{*}{ SD } & \multirow{2}{*}{ CV\% } & \multirow{2}{*}{$\operatorname{Min}(x)$} & \multirow{2}{*}{$\operatorname{Max}(x)$} & \multirow[t]{2}{*}{$x^{2}$} & \multirow{2}{*}{ Remark } \\
\hline & A & B & C & D & $E$ & $\mathbf{F}$ & & & & & & & & \\
\hline $\mathrm{Cd}$ & 0.08 & 0.08 & ND & ND & 0.001 & ND & 0.161 & 0.053 & 0.05 & 84.91 & 0.001 & 0.08 & 0.0784 & NS \\
\hline $\mathrm{Ni}$ & 0.14 & 0.22 & ND & ND & 0.16 & 0.19 & 0.85 & 0.17 & 0.034 & 20 & 0.14 & 0.22 & 0.015 & NS \\
\hline
\end{tabular}

$K E Y ; A=$ Solanum macrocarpon, $B=$ Strichium sparganophora, $C=$ Crassocephallum crepidiodes,$D=$ Solanum nigrum, $E=$ Myrianthus arboreus, $F=$ Sterculia tragacantha

Table 4. Calculated mineral ratios of Six Selected Wild Edible Vegetables

\begin{tabular}{|c|c|c|c|c|c|c|c|c|c|c|}
\hline \multirow[t]{2}{*}{ Mineral ratio } & \multirow[t]{2}{*}{ Standard } & \multicolumn{6}{|c|}{ Sample } & \multirow[t]{2}{*}{ Mean } & \multirow[t]{2}{*}{ SD } & \multirow[t]{2}{*}{$\mathrm{CV} \%$} \\
\hline & & $\mathbf{A}$ & B & C & D & $\mathbf{E}$ & $\mathbf{F}$ & & & \\
\hline $\mathrm{Na} / \mathrm{K}$ & 0.06 & 0.67 & 0.72 & 0.25 & 0.26 & 1.65 & 0.42 & 0.66 & 0.52 & 78.78 \\
\hline $\mathrm{K} / \mathrm{Na}$ & 5.0 & 1.48 & 1.39 & 3.98 & 3.77 & 0.61 & 2.40 & 2.27 & 1.36 & 59.91 \\
\hline $\mathrm{Ca} / \mathrm{P}$ & $\geq 0.5$ & 1.57 & 1.70 & 2.29 & 1.94 & 2.25 & 2.24 & 1.99 & 0.31 & 15.58 \\
\hline $\mathrm{Ca} / \mathrm{Mg}$ & 6.67 & 2.47 & 1.74 & 0.77 & 0.73 & 9.50 & 0.62 & 2.64 & 3.44 & 130.30 \\
\hline $\mathrm{Na} / \mathrm{Mg}$ & 4.17 & 2.25 & 1.79 & 0.34 & 0.39 & 6.95 & 0.43 & 2.02 & 2.55 & 126.23 \\
\hline $\mathrm{Ca} / \mathrm{K}$ & 4.0 & 0.74 & 0.70 & 0.57 & 0.49 & 2.26 & 0.60 & 0.89 & 0.68 & 76.40 \\
\hline$[\mathrm{K} /(\mathrm{Ca}+\mathrm{Mg})]$ & 2.2 & 0.96 & 0.91 & 0.76 & 0.86 & 0.40 & 0.63 & 0.75 & 0.21 & 28.00 \\
\hline $\mathrm{Zn} / \mathrm{Cu}$ & 4.75 & 1.75 & 2.02 & 1.66 & 1.89 & 0.59 & 0.43 & 1.39 & 0.69 & 49.64 \\
\hline $\mathrm{Fe} / \mathrm{Cu}$ & 5.59 & 2.49 & 3.16 & 2.71 & 3.16 & 1.11 & 1.08 & 2.29 & 0.95 & 41.48 \\
\hline $\mathrm{Ca} / \mathrm{Pb}$ & & 0 & 0 & 15,155 & 6,925 & 3,418 & 2,718 & 4.591 & $5,236.5$ & 114.80 \\
\hline $\mathrm{Fe} / \mathrm{Pb}$ & & 0 & 0 & 111 & 69.5 & 19.67 & 12.0 & 35.36 & 45.12 & 124 \\
\hline $\mathrm{Zn} / \mathrm{Cd}$ & & 18.25 & 14.38 & 0 & 0 & 310 & 0 & 57.11 & 124.15 & 217.39 \\
\hline
\end{tabular}

Chi-square $\left(X^{2}\right)$ at $p_{=0.05,} U=n-1=3$ critical value $=11.07, S=$ results significantly different, $N S=$ results not significantly different
$K E Y: A=$ Solanum macrocarpon, $B=$ Strichium sparganophora, $C=$ Crassocephallum crepidiodes,$D=$ Solanum nigrum, $E=$ Myrianthus arboreus,$F=S$ Sterculia tragacantha 
Table 5. Mineral safety index (MSI) of $\mathrm{Na}, \mathrm{Mg}, \mathrm{P}, \mathrm{Ca}, \mathrm{Fe}, \mathrm{Zn}, \mathrm{Cu}$

\begin{tabular}{|c|c|c|c|c|c|c|c|c|c|c|c|c|c|c|c|c|c|c|c|c|c|}
\hline \multirow[t]{2}{*}{ Sample } & \multicolumn{3}{|c|}{$\mathrm{Na}$} & \multicolumn{3}{|c|}{$\mathbf{M g}$} & \multicolumn{3}{|c|}{$\mathbf{P}$} & \multicolumn{3}{|c|}{$\mathrm{Ca}$} & \multicolumn{3}{|c|}{$\mathrm{Fe}$} & \multicolumn{3}{|c|}{$\mathrm{Zn}$} & \multicolumn{3}{|c|}{$\mathrm{Cu}$} \\
\hline & $\begin{array}{l}\text { TV of } \\
\text { MSI }\end{array}$ & $\mathrm{CV}$ & D & TV & CV & D & TV & $\mathrm{CV}$ & D & TV & $\mathrm{CV}$ & D & TV & CV & D & TV & CV & D & TV & $\mathrm{CV}$ & D \\
\hline$A$ & 4.80 & 0.53 & 4.27 & 15.0 & 0.93 & 14.07 & 10.0 & 0.32 & 9.68 & 10.0 & 0.51 & 9.49 & 6.70 & 0.92 & 5.78 & 33.0 & 3.21 & 2.98 & 33.0 & 9.13 & 23.87 \\
\hline B & 4.80 & 0.47 & 4.43 & 15.0 & 1.04 & 13.96 & 10.0 & 0.24 & 9.76 & 10.0 & 0.04 & 9.96 & 6.70 & 0.80 & 5.90 & 33.0 & 1.50 & 31.50 & 33.0 & 6.27 & 26.73 \\
\hline C & 4.80 & 0.64 & 4.16 & 15.0 & 7.34 & 7.66 & 10.0 & 0.55 & 9.45 & 10.0 & 1.26 & 8.74 & 6.70 & 0.50 & 6.20 & 33.0 & 1.83 & 31.17 & 33.0 & 4.51 & 28.49 \\
\hline D & 4.80 & 0.71 & 4.09 & 15.0 & 7.09 & 7.91 & 10.0 & 0.59 & 9.41 & 10.0 & 1.15 & 8.85 & 6.70 & 0.62 & 6.08 & 33.0 & 0.68 & 32.32 & 33.0 & 4.84 & 28.16 \\
\hline $\mathrm{E}$ & 4.80 & 0.72 & 4.08 & 15.0 & 0.41 & 14.59 & 10.0 & 0.38 & 9.62 & 10.0 & 0.85 & 9.15 & 6.70 & 0.26 & 6.44 & 33.0 & 0.64 & 32.36 & 33.0 & 5.83 & 27.17 \\
\hline $\mathrm{F}$ & 4.80 & 0.87 & 3.93 & 15.0 & 7.96 & 7.04 & 10.0 & 0.48 & 9.52 & 10.0 & 1.08 & 8.92 & 6.70 & 0.19 & 6.51 & 33.0 & 10.38 & 22.62 & 33.0 & 7.37 & 25.63 \\
\hline Mean & - & 0.656 & 4.14 & - & 4.13 & 10.87 & - & 0.426 & 9.57 & - & 0.82 & 9.19 & & 0.55 & 6.51 & - & 3.04 & 35.49 & - & 6.33 & 26.68 \\
\hline SD & - & 0.144 & 0.14 & - & 3.67 & 3.67 & - & 0.136 & 0.14 & - & 0.46 & 0.46 & & 0.289 & 0.29 & - & 3.71 & 11.63 & - & 1.72 & 1.17 \\
\hline CV\% & - & 21.95 & 3.38 & - & 88.66 & 33.76 & - & 31.92 & 1.46 & - & 56.10 & 5.01 & & 52.55 & 4.45 & - & 122.0 & 32.00 & - & 27.17 & 4.39 \\
\hline
\end{tabular}

$K E Y: A=$ Solanum macrocarpon, $B=$ Strichium sparganophora, $C=$ Crassocephallum crepidiodes,$D=$ Solanum nigrum, $E=$ Myrianthus rboreus,$F=$ Sterculia tragacantha

Table 6. Anti-nutrient composition (mg/100g), calculated [Phy]/[Zn], [Ca]/[Phy], [Phy]/[Fe] and [Ca] [Phy]/[Zn] Mole ratios of six wild vegetables

\begin{tabular}{|c|c|c|c|c|c|c|c|c|c|}
\hline Parameter & $\mathbf{A}$ & B & C & D & $\mathrm{E}$ & $\mathbf{F}$ & Mean & SD & CV\% \\
\hline Phytate & 38.45 & 32.40 & 41.50 & 45.50 & 48.15 & 54.60 & 43.43 & 7.77 & 17.89 \\
\hline Oxalate & 52.40 & 48.25 & 62.10 & 69.80 & 60.25 & 71.25 & 60.68 & 9.17 & 15.11 \\
\hline Cyanide & 10.01 & 12.26 & 16.62 & 19.20 & 12.05 & 11.42 & 13.59 & 3.53 & 25.97 \\
\hline Saponin & 12.85 & 10.60 & 9.25 & 11.50 & 9.60 & 12.30 & 11.02 & 1.45 & 13.16 \\
\hline $\mathrm{Ca}$ & 61.02 & 48.15 & 151.55 & 138.5 & 102.55 & 130.66 & 105.41 & 42.71 & 40.51 \\
\hline $\mathrm{Fe}$ & 2.07 & 1.80 & 1.11 & 1.39 & 0.59 & 0.72 & 1.28 & 0.59 & 46.09 \\
\hline $\mathrm{Zn}$ & 1.46 & 1.15 & 0.68 & 0.83 & 0.32 & 0.29 & 0.78 & 0.46 & 58.97 \\
\hline [Phy]/[Zn] & 2.61 & 2.71 & 4.49 & 5.43 & 14.92 & 18.67 & 8.15 & 6.88 & 84.42 \\
\hline [Ca]/[Phy] & 26.14 & 24.47 & 60.14 & 50.13 & 35.07 & 39.41 & 42.82 & 16.45 & 38.42 \\
\hline [Ca][Phy]/[Zn] & 3.97 & 3.35 & 22.85 & 18.76 & 38.16 & 60.87 & 24.66 & 21.97 & 89.09 \\
\hline$[\mathrm{Phy}] /[\mathrm{Fe}]$ & 1.57 & 1.52 & 3.16 & 2.77 & 6.91 & 6.42 & 3.73 & 2.37 & 63.54 \\
\hline
\end{tabular}

KEY: $A=$ Solanum macrocarpon, $B=$ Strichium sparganophora, $C=$ Crassocephallum crepidiodes,$D=$ Solanum nigrum, $E=$ Myrianthus rboreus,$F=$ Sterculia tragacantha 
The results of $\mathrm{Ca} / \mathrm{Phy}$ molar ratios in this present study revealed ratios above the critical level of 6:1 which is regarded as good for calcium absorption [80].The results of estimated Phy/ Ca molar ratios were cheering, predicting that $\mathrm{Ca}$ bioavailability could not be affected by the $\mathrm{Ca} /$ Phy ratio. The results were equally favourable since low ratios causes incomplete Phytate precipitation thereby leads to some of the dietary Zinc remains in solution. The proportion remaining in solution increases as a result of decreasing $\mathrm{Ca}$ : Phy molar ratios [81]. Oxalate/Calcium molar ratios for the six selected vegetables were below the critical level that will impair calcium bioavailability. The ratio of [Ca] $x$ [Phy]: $\mathrm{Zn}$ is considered as a better predictor of $\mathrm{Zn}$ availability since [Ca] x [Phy] : [Zn] complex is a less soluble than phytate complexes formed by either of the ions alone [82]. Results of the molar ratios of [Ca] $x$ [Phy] /Zn in this study were below the critical level of $0.5 \mathrm{~mol} / \mathrm{Kg}$. The results therefore suggesting $\mathrm{Ca}$ interference was likely to affect bioavailability of $\mathrm{Zn}$ in the vegetables.

\section{CONCLUSION}

This study showed that the six indigenous wild edible vegetables are rich sources of carbohydrate, protein and minerals such as Calcium, Magnesium, and Phosphorus which play a very significant role in normal human metabolism. They can also contribute to the daily requirement of fibre and fats thus suggesting that the vegetables are nutritious. The entire calculated mineral safety index were lower than the tabulated values, this justify that no mineral overload of the vegetables to the consumer. Thus, their uses as nutritional supplements are highly promising. The vegetables contains appreciable amount of the anti-nutritional factors. The moderate amount of phytate and oxalate in these vegetables could further be reduced by the processes of cooking, boiling, heating, squeezing, bleaching and soaking in water over time to leach out the concentration of the anti-nutrients before consumption. Due to the nutritional potentials of the selected wild vegetables, it is important to stimulate interest in their cultivation and utilization beyond the traditional localities through public and dietary awareness of their nutritional status so as to increase their sustainability for improved food security in Nigeria.

\section{COMPETING INTERESTS}

Authors have declared that no competing interests exist.

\section{REFERENCES}

1. Szakaly Z. (Eds.). Elelmiszer-marketting (Food Marketting): Akademial Kiado. Budapest Hungary, 2017; ISBN 9789634540618.

2. Wargovich MJ. Anti-cancer Properties of Fruits and Vegetables. Hort. Sci. 2000, 35: 573-575.

3. Dias JS, Ryder E. World Vegetable Industry: Production Breeding Trends. Hort. Rev. 2011;38:299-356.

4. Mensah JK, Okoli RJ Ohaju-obodo JO, Eifediyi K. Phytochemical, Nutritional and Medicinal Properties of Some Leafy Vegetables consumed by Edo People of Nigeria. Afri. J. Biotech. 2008; 7(14): 23042309.

5. Olowoake A, Adebayo GO. Effect of Fertilizer Types on the Growth and Yield of Amaranthus caudatus in Ilorin, Southern Guinea Savannah Zone of Nigeria. Advances in Agriculture; 2014. http://dx.doi.org/10.1155/2014/947062

6. Eroarome MA. Nutritive Value and Antinutritive factors in four indigenous edible leafy vegetables in human nutrition. A review. Journal of Food Resources Science. 2012; 1-14.

7. Nnamani CU, Oselebe HO, Okporie EO. Aspects of ethno botany of traditional resources leafy vegetables utilized as human food in rural tropical communities. Animal Res. Int. 2017; 7: 1110-1115.

8. Champton R. The Economic Value of Wildlife in Eastern and Central Africa. Research Paper Volume 23, Institute of Development Studies, University of Dares Salaam, Tanzania, 2008.

9. Modi, M, Modi AT, Hendriks S. Potential Role of Wild Vegetables in Household Food Security: A Preliminary Case Study in Kwazulu -Natal, South Africa". Afri. J. Food Agr. Nutr. Dev. 2006; 6(1): 1-13.

10. Yakubu MT, Akanji MA, Oladiji AT. Aphrodisac Potentials of Aqueous Extract of Fadogia agrestis (Schweinf. Ex Heim) stem in Male albino rats. Asian Journal of Andrology. 2005; 7: 399 - 404.

11. Saqib Z, Malik RN, Shinwari ML, Shinwari Z. Species richness, ethno botanical species and Human settlements along a 
Himalayan altitudinal gradient: prioritizing plant conservation in Palas valley. Pakistan. Pakistan J. Bot. 2011;43: 129-133.

12. Edeoga HO, Okwu DE, Mbaebie B.O. Phytochemical Constituents of Some Nigerian Medicinal Plants. Afri. J. Biotech, 2005; 4: 685-688.

13. Southon, S. Increased Fruit and Vegetable Consumption within the EU: Potential Health Benefits. Food Res. Int. 2020; 33(No. 3-4):211-217.

14. Herrera E, Jimenez R, Aruoma, OI, Hercberg S, Sanchez-Garcia S, Fraga C. Aspect of Anti-oxidant Foods and Supplements in Health and Diseases.2009, Nutri. Rev. 2009; 67(1): S140-S144.

15. Robinson DC. Food Biochemistry and Nutritional Value. Longman Scientist and Technical Publisher; 1990.

16. Lockett CT, Calvert CC Grivetti LE. Energy and Micronutrient Composition of Dietary and Medicinal Wild Plants Consumed during Drought. Study of Rural Fulani, North East Nigeria. Int. J. Food Sci. Nutr. 2000; 51:195-208.

17. Grivetti LE, Ogle BM. Value of Traditional Foods in Meeting Macro and Micronutrient Needs: The Wild Plant Connection. Nutri. Res. Rev. 2000;13:31- 46.

18. Tisdale SL, Nelson WL, Beaton JD. Soil Fertility and Fertilizers (4 ${ }^{\text {th }}$ Eds.) New York. P: Macmillan Publishing Company. 754pp. 1990.

19. Harvest P. What is hidden hunger? Breeding Crop for Better Nutrition; 2011.

20. Ogunrotimi, DG, Kayode $\mathrm{J}$ and Odesola FA. Ethno botany and Conservation of Indigenous Vegetables in Ekiti State, Nigeria. Singapore J. Scientific Research. 2018; 8(1):8-13.

21. Schneider $M$, Norman $R$, Steyn $N$, Bradshaw D. Estimating the burden of disease attribute to low fruit and vegetable intake in South Africa. 2020; South Afr. Med. J. 2020;97(8):725-731.

22. MMWR: Morbidity and Mortality Weekly Report. Trends in Fruits and Vegetables Consumption Among Adults- United States. 2000 - 2009.MMWR.59 (35).

Avaialble:http://www.cdc.gov/mmwr/pdf/wk /mm5935.pdf [PubMed] [Goggle Scholar]

23. Ilelaboye NOA, Amoo IA, Pikuda OO. Effect of cooking methods in proximate composition, gross-energy and dietary fibre of some green leafy vegetables.
European J. Appl. Eng. Scientific Research. 2013; 2(2):41-47.

24. AOAC. Official Method of Analysis. In Association of Official Analytical Chemist, Washington D.C. 2005;106.

25. Pearson D. Chemical Analysis of Food. $7^{\text {th }}$ edn. Church Hill London. 1976:7-11.

26. Osborne DR, Voogst P. The Analysis of Nutrients in Foods. London Academic Press. $6^{\text {th }}$ Edn. 1978;239-245.

27. Wilson RP, Robinson FH, Poe WF. Apparent and true availability of amino acids from feed ingredients for channel catfish. The J. Nutr., 1981;111(5):923-929.

28. Wheeler RP, Ferrel RE, Evaluation of African Vegetables for their Nutritive Values. J. Sci. Food Agric. 1971;32: 273-278.

29. AOAC. Official methods of Analysis $\left(11^{\text {th }}\right.$ Edition). Association of Analytical Chemist, Washington DC; 2010.

30. Wyatt CJ. Triana-Tejas A.(1994). Soluble and Insoluble $\mathrm{Fe}, \mathrm{Zn}, \mathrm{Ca}$, and Phytates in foods commonly consumed in Northern Mexico. J. Agric. Food. Chem. 1994;42:2204-2209.

Avaialble:http://doi.Org/10.1021/if0004690 24.

31. International Zinc Nutrition Consultative Group (IZINCG). Assessment of the Risk of Zinc deficiency in population and options for its control. In: Hotz, C. and Brown, K.H. (Eds.). Food and Nutrition. 2004; 25(1) (Suppl.2): S113-S118.

Avaialble:http://doi.org/10.117/1564826504 025.

32. Chase Cl. Elementary Statistical Procedures, $2^{\text {nd }}$ edn. McGraw. Hill Kogakusha Ltd. Tokyo, Japan; 1976.

Avaialble:http:/doi.Org/10.1177/001316444 7603600445

33. Oloyo RA. Fundamentals of Research Methodology for Social and Applied Sciences, ROA Educational Press, llaro, Nigeria; 2001.

34. Olujobi OJ. Evaluation of the Nutritive Composition of Five Indigenous Tree Leaves Used as Vegetables in Ekiti State. J. Agr. Environ. Sci. 2015; 4(1):185-197.

35. Amata IA. Nutritive Value of the Leaves of Myrianthus arboreous. A browse Plant. Int. J. Agri. Research. 2010; 5:576-581.

36. Ilodibia CV, Akachukwu EE, Chukwuma MU, Igboabuchi NA. Proximate, Phytochemical and Antimicrobial Studies on Solanum macrocarpon L. J. Adv. Biol. Biotech. 2016; 9(2):1-7. 
37. Adeyeye El, Ayejuyo OO. Chemical Composition of Cola acuminata and Garcina kola seeds grown in Nigeria. Int. J. Food Sci. Nutri. 1994;223-230.

38. Udousoro I, Ekanem P. Assessment of Proximate Compositions of twelve edible vegetables in Nigeria. Int. J. Modern Chem. 2013;4(2):79-89.

39. Lai H. A Textbook of Biochemistry, $1^{\text {st }}$ Edn. $: 2^{\text {nd }}$ reprint. CBS Publishers and Distributors. New Delhi. 2008;1-497.

40. Onwordi C, Ogungbade AM, Wuse AD. The Proximate and Mineral Composition of Three Leafy Vegetables Commonly Consumed in Lagos. Afr. J. Pure Appl. Chem. 2009;3:102-107.

41. Oyeyemi SD, Arowosegbe S, Adebiyi AO. Phytochemical and Proximate Evaluation of Myrianthus arboreus (P. Beau.) and Spargonophoprus sporgonophora (Linn.) Leaves. IOSR Journal of Agriculture and Veterinary Science (IOSR-JAVS). 2014; 7(9 ver.1):01-05.

42. Akinwumi OA. Omotayo FO. Proximate Analysis and Nutritive Value of Ten Common Vegetables in South-West (Yoruba Land) Nigeria. Communication in Applied Science. 2016;4(2):79-91.

43. Sobowale SS, Olatidoye OP, Olorode OO, Akinlotan JV. Nutritional Potentials and Chemical Value of Some Tropical Leafy Vegetables Consumed in South West Nigeria. J. Sci. Mult. Res. 2011;3:55-61.

44. Olujobi OJ. Evaluation of the Nutritive Composition of Five Indigenous Tree Leaves Used as Vegetables in Ekiti State. Journal of Agriculture and Environmental Sciences. 2015;4(1):185-197.

45. Emebu PK, Anyika JU. Proximate and Mineral Composition of Kale (Brassica oleraceae) grown in Delta State, Nigeria. Pak. J. Nutri. 2011;19: 190-194.

46. Ayeni MJ, Oyeyemi SD, Kayode J, Peter, G.P Phytochemical, Proximate and Mineral Analyses of the Leaves of Gossypium hirsutum L. and Momordica charantia L. J. Nat. Sci. Research.2015; 5(6):99-107.

47. Igile GO, Iwara IA,.Mgbee BIA, Uboh FE, Ebong PE. Phytochemical, Proximate and Nutrient Composition of Vernonia calvaona Hook (Asteraceae): A green leafy vegetable in Nigeria. J. Food Research. 2013; 2(6):1-11.

48. Nwankwo CS, Ebenezer I, Ikpeama Al, Asuzu FO.The Nutritional and Antinutritional Values of two Culinary Herbs-
Uziza leaf (Piper guineense) and scent leaf (Ocimum gratissimum) popularly used in Nigeria. Int. J. Scientific. Eng. Research. 2014; 5(12):1160-1163.

49. Ejoh AR, Tchouanguep MF, Fokou E. Nutrient Composition of the Leaves and Flowers of Colocasia esculenta and the fruits of Solanum melongata. Plant Food for Human Nutr. 1996;49:107-112.

50. Fagbohun ED, Lawal OU, Ore ME. The Proximate, Minerals and Phytochemical Analysis of the Leaves of Ocimum grattissimum L., Melanthera scandens A. and Leca guineensis $\mathrm{L}$. and their medicinal value. Int. J. Appl. Biol. Pharm. Technol. 2012; 3:15-22.

51. Ifo $\mathrm{El}$, Basir O. The Nutritive Value of Some Nigerian Leafy Green Vegetable: The Distribution of Protein, Carbohydrate, Crude Fibre and Ash. Food Chem. 1980;1:231-235.

52. Okon JE, Christopher MA, Okey EN, Ibanga IA. Nutraceutical Potentials of Wild and Neglected Leafy Vegetables (Sterculia tragantha and Sesamum indicum) in Akwa lbom State, Nigeria. European J. Biomed. Pharm. Sci. 2019;6(3):30-36.

53. Adjatin A, Dansi A, Badoussi E, Sanoussi AF, Dansi M, Azokpota $P$, Ahisou $H$, Akouegninou A, Akpagana K, Sanni A. Proximate, Mineral and Vitamin Composition of Vegetables Gbolo (Crassocephalum rubens (Juss.ex.Jacg.) $\mathrm{S}$. Moore and C. crepidiodes (Benth) S. Moore in Benin. Int. Biol. Chem. Sci. 2013;7(1):319-331.

54. Min AM, Ngone AM, Ndam L.M. Assessment of Nutritional Composition of Wild Vegetables Consumed by the People of Lebialem Highlands, South Western Cameroon. Food Nutr. Sci. 2017; 8: 647 657.

55. WHO. Global Energy on diet, physical activity and health: Resolution WHA 57: 17. (France), 2004

56. Alinor IJ, Oze R. Chemical Evaluation of the nutritive value of Pentaclethra macrophylla Benth (African Oil Bean) Seeds. Pakistan J. Nutri. 2011;10(4): 355- 359.

57. Ajayi OB, Akomolafe SF, Akinyemi FT. Food Value of Two Varieties of Ginger (Zingiber officinale). Commonly Consumed in Nigeria. ISRN Nutrition; 2013.

Avaialble:http://dx.doi.org/10.5402/2013/35 9727 
58. Oibiokpa FI, Adoga GT, Saidu AN, Shittu KO. Nutritional Composition of Detarium microcarpon fruit. African Journal of Food Science. 2014; 8(6):342-350.

DOI. 10. 58888897/AJFS 2014.1161http: //www.cademicjournals.org/AJFS

59. Soetan KO, Olaiya CO, Oyewole OE. The importance of Mineral Elements for Humans, Domestic Animals and Plants. A Review: Afr. J. Food Sci. 2010; 4(5): 200-202.

60. Wardlaw GM, Hampl JS, DiSilvestro RA. Perspectives in Nutrition. $6^{\text {th }}$ Edition. New York: McGraw Hill. 2004; 67-84.

61. Eze MI, Nwibo OO. Effects of Processing on Proximate Composition of Hibiscus rosa- sinensis Leaf. European Journal of Medicinal Plants. 2017; 18(2):1-13.

62. Akubugwo IE, Obasi AN, Ginika SC. Nutritional Potential of the Leaves and Seeds of Black Nightshade Solanum nigrum L. var Virginicum from Afikpo, Nigeria. Pakistan J. Nutri. 2007;6(4): 323-326

63. Adeyeye El, Otoketi MKO. Proximate Composition of some nutritional valuable minerals of two varieties of Capsicum annum (Bell and Cherry peppers). Discovery and Innov. II (1\&2):1999; 75-81.

64. Pathak JL, Kapil GF. Mineral Composition of Some Leafy Vegetables Consumed in Kano, Nigeria. Nigerian J. Basic and Appl. Sci. 2004; 19(2):208-211.

65. Deluccia R, Cheurg M, Ng T, Ramadoss R, Altasan A, Sukumar D. Calcium to Magnesium Ratio Higher than Optimal Across Age Groups (P10 -100 -19). Curr. Dev. Nutri., 3(1). Issue Supplement2019;1:868-869.

66. Amos A, Alvan A. Florence A. The Antinutritional Effect of Phytate on Zinc, Iron and Calcium Bioavailability of some Cereals Staple foods in Zaria, Nigeria. European Journal of Nutrition and Food Safety, 2020; 12(1):1-6.

67. Ertop M.H, Bektas M. Enhancement of Bioavailable Micronutrients and Reduction of Anti-nutrients in Foods with some Processes. Food and Health. 2018; 4(3):159 -165.

68. Awotedu OL, Ogunbamowo PO. Nutritional, Anti-Nutritional and Phytochemical Profile of the Leaves and Fruits of Synsephalum dulcicum (Schumach. \& Thonn.) Daniell. American J. Biol. Chem. 2019; 7(3):53-59.
69. Reddy NR. Occurrence, Distribution. Content and Dietary Intake of Phytate. In: Reddy, N.R., Saller, S.K. Eds. Food Phyates. London: CRC Press: 2020:30-32.

70. Hamalu BP. The adverse effect of long term cassava (Manihot esculenta Grantz) consumption. Int. J. Food Sci. Nutr. . 1995;46:65-93.

71. FAO/WHO. Protein Quality Evaluation Report of Joint FAO/WHO Expert Consultation FAO. Food and Nutrient, FAO, Rome, Italy; 1991.

72. American Diabetic Association. Urolithiasis/urinary stones. In: ADA Nutritional Manual. Chicago II. ISA. 2005;483-486.

73. Sanz P, Reig R. Clinical and Pathological Findings in Fatal Plant Oxalosis. The American Journal of Forensic Medicine and Pathology. 1992;13: 342-345.

74. Kataria B, Chanchan M, Punia D. Antinutrients in amphilidiloids (blackgrain \& mung bean) varietal differences and effect of domestic processing and cooking. Plant Food and Human Nutr. 1989; 39: 257-266.

75. Doss A, Puyalenthi M, Vadivel VG, Subhashini G, Anitha Subash R. Effects of Processing Technique on the Nutritional Composition and Anti- nutrients content of Under-utilized Legume Canavalia ensiformis L. DC. Int. Food Research J. 2011;18(3):125-140.

76. Chai-Fai C, Peter C-Kc, Shung WY. Effect of Cooking on content of Amino-acids and Anti-nutrients in the Chinese Indigenous Legume Seed. J. Sci. Food Agri. 1997;75:447-452.

77. Turland JR, King JC, Keyes WR, Gong B, Michel MC. (1984). A Stable Isotope Study of Zinc Absorption in young men. Effects on Phytate and a-cellulose. Am. J. Cli. Nutr., 1984;40:1071-1077.

78. Hurell RF. Bioavailability a time for reflection. Inter. J. Vit. Nutri. Res. 2002;72(1): 5- 6.

79. Taylor PG. Mendez- Castellanos H, Landaeta- Junenez, $M$. et al. Iron bioavailability from diets consumed by different socio economic strata of the Venszuslan Population. J. Nutr. 1995;125:1860-1865.

80. Akin- Idowu PE, Aseidu R, Maziya-Dixon B, Odunola A, Uwaifo A. Effect of two processing methods on some antnutritional factors in yellow yam (Dioscorea 
cayenensis). African Journal of Food Science. 2009;3(1): 022- 025.

81. Wise, A .Dietary Factors determining the Biological Activities of Phytate. Nutr. Abst. Rev/Rev. Clin. Nutr. 1983; 53:791-806.
82. Lopex HW, Leenhardt F, Coudray C. Remesy C. Minerals and Phytic acid interactions: is it a real problem for human nutrition? Int. J. Food Sci. Tech. 2002;37(7):727-739.

(c) 2021 Ayeni and Oyeyemi; This is an Open Access article distributed under the terms of the Creative Commons Attribution License (http://creativecommons.org/licenses/by/4.0), which permits unrestricted use, distribution, and reproduction in any medium, provided the original work is properly cited.

Peer-review history:

The peer review history for this paper can be accessed here:

https://www.sdiarticle5.com/review-history/78788 